\title{
Immunological Basis of Serum Resistance of Neisseria gonorrhoeae
}

\author{
By HERMAN SCHNEIDER, ${ }^{*}$ J. MCLEOD GRIFFISS, + \\ GLYNNE D. WILLIAMS AND GERALD B. PIER $\dagger$ \\ Department of Bacterial Diseases, Walter Reed Army Institute of Research, Washington, \\ D.C. 20012, U.S.A.
}

(Received 3 March 1981)

\begin{abstract}
The immunological basis for resistance of certain strains of Neisseria gonorrhoeae to the bactericidal action of normal human serum was studied by investigating the potential role of factors which are known to interfere with each of the sequential steps that result in immune lysis of Gram-negative bacteria. Strains of $N$. gonorrhoeae were characterized as serum-sensitive $\left(\operatorname{ser}^{\mathrm{s}}\right)$ or serum-resistant $\left(\operatorname{ser}^{\mathrm{r}}\right)$ on the basis of their sensitivity to lysis by the sera of six normal individuals. Neither intrinsic resistance to the lytic action of activated human complement nor inaccessibility of the cell membrane to $\overline{\mathrm{C}} \overline{5} \bar{b}$ accounted for ser ${ }^{r}$. Outer membrane lipopolysaccharide (LPS) was the target antigen for lytic antibody in normal human sera. The gross chemical composition and molecular size of the LPS of the strains were heterogeneous and no consistent patterns of differences between those extracted from $\operatorname{ser}^{r}$ and from $\operatorname{ser}^{\text {s }}$ strains were found. Neither IgA nor IgG 'blocking' antibody in normal human serum was responsible for ser ${ }^{r}$. We conclude that ser $^{r}$ results from the absence from the LPS of the strains of antigenic loci for the lytic antibody in most normal human sera, or, expressed as a function of the host, the absence from the sera of most normal humans of lytic antibody directed against LPS antigenic loci for immune lysis.
\end{abstract}

\section{INTRODUCTION}

Strains of Neisseria gonorrhoeae vary in their susceptibility to the bactericidal action of normal human sera (NHS) (Glynn \& Ward, 1970; Tramont et al., 1977; Rice et al., 1980), which action is the primary barrier to dissemination of potentially pathogenic strains of Neisseria from mucous membrane sites of colonization (Goldschneider et al., 1969; Schoolnik et al., 1976; Nicholson \& Lepow, 1979; Brooks et al., 1976). Serum sensitivity $\left(\mathrm{ser}^{\mathrm{s}}\right.$ ) of strains of $N$. gonorrhoeae results from immune lysis, i.e. it is complement-mediated and dependent upon 'naturally' acquired antibody directed at outer membrane lipopolysaccharide (LPS) antigenic determinants (Glynn \& Ward, 1970; Tramont et al., 1977). Understanding the basis of serum resistance (ser $\left.{ }^{r}\right)$ of strains of $N$. gonorrhoeae is of great importance, since only ser $^{\mathrm{r}}$ strains produce disseminated disease (Schoolnik et al., 1976). Prevention of disseminated disease by immunoprophylaxis will be feasible only if $\operatorname{ser}^{r}$ results from the absence of natural antibody directed at appropriate surface antigenic loci, and if such antibody can be induced in humans by vaccination.

Classical immune lysis requires the presence of surface antigens which bind either IgM or IgG-doublets which are then capable of binding to and activating $\mathrm{C}$ 1, leading to the generation of $\overline{\mathrm{C} 5 \mathrm{~b}}$ which embeds in the lipid bilayer of the outer membrane of the bacterium and activates the remaining complement components (C6-C9). This results in enzymic damage to the membrane, disruption of osmoregulation and, finally, lysis (Frank, 1979). The

† Present address: Channing Laboratory, 180 Longwood Avenue, Boston, Massachusetts 02115, U.S.A. 
failure to complete any of the sequential steps prevents lysis and allows survival of the bacterium, or serum resistance. This can result from the absence, either absolute or functional, of antigen, antibody or complement. Functional absence of antigen may result from masking of antigen by other surface components (Reynolds \& Rowley, 1969); functional absence of antibody may reflect the presence of blocking antibody (Griffiss \& Bertram, 1977; McCutchan et al., 1978) or the inability of specific antibody to activate C1. Functional absence of complement results from the failure to generate $\overline{\mathrm{C} 9}$ either due to deficiencies in C6, C7 or C8 (Petersen et al., 1976; Nicholson \& Lepow, 1979) or the failure of $\overline{\mathrm{C}} \overline{\mathrm{b}}$ to embed in the membrane of the bacterium. This latter failure may be because of the absence of a permissive lipid bilayer, as in Gram-positive bacteria (Frank, 1979), because cell surface structures physically hinder association of $\overline{\mathrm{C} 5 \mathrm{~b}}$ with the cell membrane (Reynolds et al., 1975), or because the site of complement activation is sufficiently removed, physically, from the cell surface that $\overline{\mathrm{C} 5 \mathrm{~b}}$ diffuses before embedding in the cell membrane (Reynolds \& Rowley, 1969; Frank, 1979).

Each of these mechanisms has been invoked but not demonstrated to explain $\operatorname{ser}^{r}$ of $N$. gonorrhoeae (Ward et al., 1978). The present studies were undertaken to investigate the role of each of these factors in producing the phenomenon of ser ${ }^{r}$. The data indicate that $\operatorname{ser}^{r}$ results from the absence of natural antibody directed against LPS determinants which serve as lytic loci on $\operatorname{ser}^{\mathrm{T}}$ strains.

\section{METHODS}

Bacterial strains and cultural procedures. Neisseria gonorrhoeae strains were selected randomly from the collection of the Department of Bacterial Diseases, Walter Reed Army Institute of Research. They were isolated from cases in several cities in the U.S.A., Canada and Japan. No effort was made to ensure any particular clinical or epidemiological representation. They were identified as $N$. gonorrhoeae by Gram-stained morphology, oxidase reaction and carbohydrate fermentation patterns. Colony type 1 organisms (Kellogg et al., 1963) were used in all experiments. Stocks of each strain, prepared from subcultures of lyophilized organisms, were maintained at $-70^{\circ} \mathrm{C}$ and cultured on GC medium base agar (Difco) containing $1 \%(\mathrm{v} / \mathrm{v})$ defined supplement (White \& Kellogg, 1965) (GCD) at $37^{\circ} \mathrm{C}$ in humidified candle extinction jars.

Salmonella minnesota strain SF1111 and its rough isogenic mutants SF1112 (Ra), SF1119 (RcP-) and SF 1167 (Re), obtained from Dr Peter Gemski, Walter Reed Army Institute of Research, were maintained as stock cultures at $-70^{\circ} \mathrm{C}$. Cultures were grown on Trypticase Soy Agar (TSA; from BBL) at $37^{\circ} \mathrm{C}$; the stability of the Re mutant, which tends to revert to a less rough state, was monitored by simultaneously culturing SF 1167 on MacConkey agar, a medium which inhibits growth of Re mutants.

Normal human serum (NHS). NHS was obtained from volunteers in our laboratory, none of whom admitted to a history of infection with $N$. gonorrhoeae; sera were processed at $4{ }^{\circ} \mathrm{C}$ to preserve complement and stored at $-70^{\circ} \mathrm{C}$. Serum from each individual was tested separately.

Bactericidal test $(B C T)$. For each test, a fresh vial of frozen NHS (intrinsic complement) was thawed and serially diluted twofold with Geys' balanced salt solution (GBSS) containing $0.5 \%(\mathrm{w} / \mathrm{v})$ bovine serum albumin (GBSS/BSA). Portions of each of the serum dilutions were removed to fresh tubes and heated to $56^{\circ} \mathrm{C}$ for $30 \mathrm{~min}$ to inactivate complement. The inocula, prepared in GBSS/BSA from 16-18 h GCD agar cultures, were adjusted to contain $1-2 \times 10^{5}$ organisms $\mathrm{ml}^{-1}$. The BCT reaction mixtures were prepared by adding, sequentially, $0.05 \mathrm{ml}$ of either untreated or heat-inactivated serum and $0.05 \mathrm{ml}$ of inoculum to $0.4 \mathrm{ml}$ of GBSS/BSA. The BCT components were held in an ice bath until all of the mixtures were assembled, after which the mixtures were incubated at $37^{\circ} \mathrm{C}$ for $45 \mathrm{~min}$ in a shaking water bath. Samples $(20 \mu \mathrm{l})$ were removed from each reaction mixture, spotted on GCD plates and then spread by tilting the plates, allowing the samples to run the length of the plate. Results using this procedure did not differ from those obtained when mixtures were assayed by plating larger samples on single GCD plates. Colonies produced by surviving organisms were counted after $18 \mathrm{~h}$ incubation. Bactericidal activity was determined by comparing the numbers of survivors in reaction mixtures containing dilutions of active serum (intact complement) with the survivors in mixtures containing similar dilutions of heat-inactivated serum.

Preparation of rabbit immunoglobulin (Ig). Hyperimmune antisera to serr strain 7134 were raised in rabbits by six intravenous inoculations of increasing doses $(0.1$ to $1.0 \mathrm{ml})$ of a saline suspension of formalin $(0.3 \%)$ killed organisms $\left(A_{650} 1.0\right)$ given over 2 weeks. After an interval of 1 week, animals received an additional $1.0 \mathrm{ml}$ dose and were bled by cardiac puncture 1 week later. (In conducting the research described in this report, the 
investigator(s) adhered to the Guide for the Care and Use of Laboratory Animals as promulgated by the Committee on Care and Use of Laboratory Animals of the Institute of Laboratory Animal Resources, National Research Council.] Ig was precipitated with an equal volume of $70 \%$ saturated ammonium sulphate. Precipitated Ig was washed three times with $35 \%$ saturated ammonium sulphate, then dissolved in distilled water, dialysed for $2 \mathrm{~d}$ against distilled water and restored with distilled water to the original volume of serum.

Bactericidal activity of rabbit Ig. The bactericidal activity of rabbit antiserum and Ig was determined by modifying the BCT so that $0.05 \mathrm{ml}$ volumes of heat-inactivated dilutions of whole rabbit serum or Ig fraction replaced GBSS/BSA diluent keeping the total reaction volume $(0.5 \mathrm{ml})$ constant. NHS, which was without bactericidal activity for $\operatorname{ser}^{\mathrm{r}}$ strains, served as a source of complement.

Effect of sensitizing media on serum resistance. The sensitivity of normally $\operatorname{ser}^{r}$ smooth strains of $S$. typhimurium to the lethal action of antibody and complement is increased in the presence of Tris or Tris plus EDTA. This treatment permits association of $\overline{\mathrm{C} 5 \mathrm{~b}}$ with the cell membrane, a requisite intermediate step in immune lysis which is normally impeded by smooth LPS (Reynolds et al., 1975).

In order to determine if similar LPS protection accounts for $\operatorname{ser}^{r}$ of $N$. gonorrhoeae strains, the BCT was performed in a 'sensitizing' medium (TSB) consisting of $0.1 \mathrm{M}$-Tris $\mathrm{pH} 7.0$, with $0.5 \%(\mathrm{w} / \mathrm{v}$ ) BSA and $0.2 \mathrm{M}$-sucrose to stabilize the organisms and improve survival. In the BCT, TSB replaced GBSS/BSA as the diluent and the test was performed using strains $7134\left(\mathrm{ser}^{r}\right)$ and $\mathrm{F} 62\left(\mathrm{ser}^{\mathrm{s}}\right)$. Experiments were also performed with the addition of $2 \mathrm{~mm}-\mathrm{Mg}^{2+}$ to TSB and with the substitution of GBSS for distilled water in the formulation of the sensitizing medium. Because survival rates of $N$. gonorrhoeae in the presence of EDTA were low (no survivors at $50 \mu \mathrm{g} \mathrm{ml}^{-1}$ and only $24 \%$ survival at $5 \mu \mathrm{g} \mathrm{m}^{-1}$ ), we could not test its effect in the presence of Tris.

Ig class studies. IgA was removed from NHS by absorption to $\alpha$-chain specific, goat antihuman IgA antibody covalently coupled to an insoluble matrix (Sepharose 4B; Pharmacia) (Griffiss \& Bertram, 1977). IgM was purified from NHS by the previously described GV-2 method of continuous, in-line chromatography over molecular sieve, ion-exchange and immunoadsorbent affinity gels (Griffiss et al., 1978).

Extraction and purification of lipopolysaccharide. LPS of $N$. gonorrhoeae strains and of $S$. minnesota strains SF 1112 and SF 1119 were extracted from acetone-dried organisms by a modification (Bertram et al., 1976) of the hot phenol/water method (Westphal \& Jann, 1965). LPS of S. minnesota strain SF 1167 (Re) was extracted from acetone-dried organisms by the phenol/chloroform/petroleum ether method (Galanos et al., 1969).

Effect of LPS on complement activity. Samples of LPS $(200 \mu \mathrm{l})$, diluted in triethanolamine-buffered saline (TBS) to contain from 400 to $3.12 \mu \mathrm{g}$ LPS, were added to chilled tubes containing $0.1 \mathrm{ml}$ of freshly thawed, undiluted NHS. The mixtures were adjusted to $0.4 \mathrm{ml}$ with triethanolamine-buffered saline and incubated for $30 \mathrm{~min}$ at $37^{\circ} \mathrm{C}$. Each mixture was then assayed for haemolytic complement activity by the procedure of Hook \& Muschel (1964).

Inhibition of bactericidal activity by LPS. The specificity of bactericidal activity of NHS was determined by inhibition with purified LPS. NHS $(0.05 \mathrm{ml})$, diluted in GBSS/BSA to give $90-95 \%$ lysis of the test strain, was mixed with LPS $(0.31-20 \mu \mathrm{g})$. After adding $0.3 \mathrm{ml} \mathrm{GBSS} / \mathrm{BSA}$, the reaction mixture was incubated for $30 \mathrm{~min}$ at $37^{\circ} \mathrm{C}$; the test inoculum $(0.05 \mathrm{ml})$ was then added and incubation continued for a further 45 min. Inhibitory activity of LPS was determined by comparing the percentage of the test organisms killed by serum alone with that killed by mixtures of LPS and serum.

Physical characterization of LPS. The molecular size of LPS extracted from strains of $N$. gonorrhoeae and $S$. minnesota was estimated by ascending recycling chromatography (Schneider et al., 1978). LPS was disaggregated in $3 \%(\mathrm{w} / \mathrm{v})$ sodium deoxycholate in $0.1 \mathrm{M}$-borate-buffered saline $\mathrm{pH} 8.3$ and cycled three times over $100 \mathrm{~cm}$ of Sephadex G-50 Superfine (Pharmacia). The void and bed volumes of this chromatographic system were determined using Sephadex Blue Dextran (Pharmacia) and phenol red. respectively. Ovalbumin (mol. wt 45000 ). chymotrypsinogen A (25000), ribonuclease (13700) and cytochrome $c$ (13200) were used as markers for molecular size. The latter was co-chromatographed with LPS to provide a visual marker for each chromatography cycle. The molecular weight of the fully oxidized fraction of cytochrome $c$, used as the visual and molecular size marker, was determined by chromatography over $45 \mathrm{~cm}$ of Sephadex G-75 Superfine (Pharmacia), calibrated with the other three globular proteins. For the recycling chromatographic system, a plot of the $\log$ of the molecular weight of each of the calibrating proteins against $K_{\text {av }}$ yielded a correlation coefficient of 0.98 . LPS was detected by testing third-cycle eluate fractions for the presence of 2-keto-3-deoxyoctonate (KDO); globular proteins were monitored by measuring $A_{206}$ and $A_{260}$. For each LPS preparation. the $K_{\mathrm{av}}$ of the fractions containing the highest concentration of KDO was determined, and its molecular weight was estimated algebraically from the function describing the correlation of molecular weight and $K_{\mathrm{av}}$ for the globular proteins.

Chemical characterization of LPS. The content of KDO was estimated colorimetrically by the thiobarbituric acid method of Osborn (1963) in LPS which had been dried under vacuum at $60^{\circ} \mathrm{C}$ over $\mathrm{P}_{2} \mathrm{O}_{5}$ in an Abderhalden apparatus: it was expressed as the \% KDO relative to dry weight. Neutral hexose content was estimated colorimetrically by the anthrone method of Roe (1955).

Gas-liquid chromatography (g.l.c.) was used to identify and quantify the carbohydrates and lipids in extracted LPS, using a Hewlett-Packard 5830 gas chromatograph. Lipid and polysaccharide portions of the LPS were 
separated by hydrolysis at $95^{\circ} \mathrm{C}$ with $1 \%(\mathrm{v} / \mathrm{v})$ acetic acid for $16 \mathrm{~h}$. The insoluble lipid was recovered by centrifugation $(5000 \mathrm{~g})$ and washed three times with distilled water. The soluble carbohydrates in the supernatant and the three distilled water washes were extracted three times with each of chloroform and hexane and were lyophilized. Monosaccharides were released by hydrolysis with $3 \%(\mathrm{v} / \mathrm{v})$ methanolic $\mathrm{HCl}$ at $95^{\circ} \mathrm{C}$ for $5 \mathrm{~h}$. Trimethylsilyl derivatives of the monosaccharides were prepared according to Pier et al. (1978), separated on a $1.8 \mathrm{~m} \times 4 \mathrm{~mm}$ (i.d.) column of $3 \%$ SE-30 on GasChrom $\mathrm{Q}$ (Supelco) and detected with a flame-ionization detector. The lipid portion was hydrolysed with $12 \%(\mathrm{v} / \mathrm{v})$ methanolic $\mathrm{HCl}$ at $95{ }^{\circ} \mathrm{C}$ for $12 \mathrm{~h}$. Methanolic $\mathrm{HCl}$ was evaporated under flowing $\mathrm{N}_{2}$, and the remaining fatty acid methyl esters were dissolved in chloroform, separated on a $1.8 \mathrm{~m} \times 2 \mathrm{~mm}$ column of $\mathrm{OV}-17$ on GasChrom Q and detected with a flame-ionization detector. The carbohydrate and fatty acid residues were also analysed in a Finnegan $3200 \mathrm{D}$ gas chromatograph/mass spectrometer equipped with methane chemical ionization. Individual g.l.c. peaks were identified by cochromatography with authentic standards, quantified by reference to an internal mannitol standard (Pier et al., 1978; Bhatti et al., 1970) and expressed as molar ratios relative to galactose (for monosaccharides) or lauric acid (for fatty acids). Mass spectroscopy fragmentation patterns were similarly identified. The standard for L-glycero-D-manno-heptose was provided by Dr Robert Shaffer (Bureau of the National Bureau of Standards, Gaithersburg, Md., U.S.A.) as D-glycero-L-manno-heptose which co-chromatographs with the L-D-isomer.

Duplicate analyses were performed on each LPS preparation. Duplicate determinations varied by $\pm 3 \cdot 5 \%$ for glucose, galactose and $\mathrm{KDO}$ and by $\pm 6 \%$ for glucosamine. Galactosamine was detected too infrequently for the inherent variation in the technique to be calculated. Two separate extractions of LPS from a single strain (F62) were also analysed to determine lot-to-lot variations.

\section{RESULTS}

Sensitivity of strains of N. gonorrhoeae to NHS. Seventeen strains of N. gonorrhoeae were tested for sensitivity to the bactericidal activity of serum donated by six members of our laboratory (Fig. 1). The strains tended to segregate into two groups: a group of seven strains which survived in the presence of undiluted sera from all six donors, and another group of seven strains which were killed in the presence of these sera diluted 1:4 or greater. The susceptibility of three strains varied with the source of the NHS and could not be classified into either category. From these results, we established the following criteria of sensitivity and resistance to NHS: strains showing $50 \%$ survival or greater in serum dilutions $\leqslant 1: 2$ were designated serum-resistant $\left(\operatorname{ser}^{r}\right)$, while strains showing less than $50 \%$ survival in serum dilutions $\geqslant 1: 4$ of at least four of six test sera were designated serum-sensitive $\left(\operatorname{ser}^{\mathrm{s}}\right)$.

Intrinsic resistance to the lytic action of complement. When either homologous immune rabbit serum or its Ig fraction were added to NHS, immune lysis of a $\operatorname{ser}^{\mathrm{r}}$ strain of $N$. gonorrhoeae proceeded completely; this activity could be titrated and did not result in prozone formation. Thus, human complement, when activated by specific antibody, was fully capable of mediating immune lysis of $\operatorname{ser}^{\top}$ strains.

Inaccessibility of the cell membrane to $\overline{C 5 b}$. When the BCT was performed in the TSB sensitizing medium, $\operatorname{ser}^{r}$ strains were no more sensitive to lysis by NHS than when tested in GBSS/BSA (Table 1). Addition of divalent cations $\left(\mathrm{Mg}^{2+}\right.$ or $\mathrm{Mg}^{2+}$ plus $\left.\mathrm{Ca}^{2+}\right)$ had no effect. TSB medium had no sparing effect on lysis of $\operatorname{ser}^{\mathrm{s}}$ strains by NHS.

Blocking antibody. Serum IgA blocks both IgM-initiated and IgG-initiated immune lysis of $N$. meningitidis and accounts for the $\operatorname{ser}^{r}$ of meningococcal strains which cause disseminated disease, i.e. absence of serum bactericidal activity (Griffiss \& Bertram, 1977). In contrast, removal of IgA from NHS did not result in immune lysis of the $\operatorname{ser}^{r}$ strain 7134 of $N$. gonorrhoeae by sera from two donors.

It has been reported that, under different experimental conditions, human IgG blocks immune lysis of $\operatorname{ser}^{r}$ strains of $N$. gonorrhoeae initiated by normal rabbit serum (McCutchan et al., 1978). IgM, purified from NHS and free of both IgG and IgA, was completely unable to initiate immune lysis of $\operatorname{ser}^{r}$ strains 7134 and WR302, but was fully able to initiate lysis of ser $^{\mathrm{s}}$ strains $\mathrm{F} 62$ and 213.

Antigenic specificity of bacterial antibody in NHS. Incubation of purified LPS from either a $\operatorname{ser}^{\mathrm{s}}$ or a $\operatorname{ser}^{\mathrm{r}}$ strain with NHS under the conditions described in Methods had no appreciable 


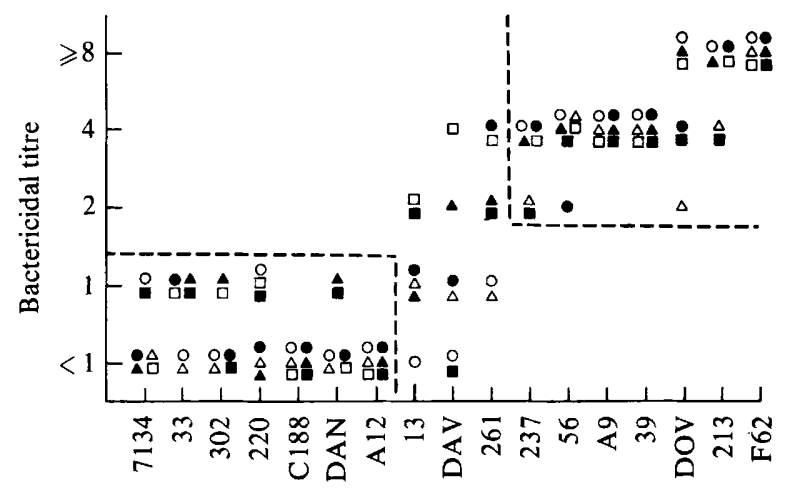

Strain

Fig. 1. Susceptibility of 17 strains of $N$, gonorrhoeae to the bactericidal activity of NHS from six

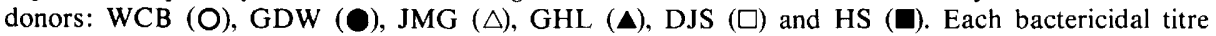
represents the reciprocal of the highest serum dilution which kills $\geqslant 50 \%$ of the organisms tested.

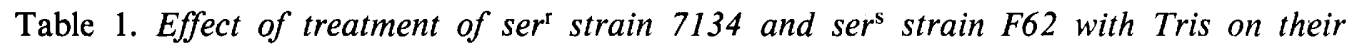
sensitivity to immune lysis by $\mathrm{NHS}$

\begin{tabular}{|c|c|c|c|c|c|c|c|}
\hline \multirow[b]{3}{*}{ Test medium* } & \multirow[b]{3}{*}{$\begin{array}{l}\text { Dilution } \\
\text { of NHS ... }\end{array}$} & \multicolumn{6}{|c|}{ Percentage killing of organisms } \\
\hline & & \multicolumn{3}{|c|}{ Strain $7134\left(\operatorname{ser}^{r}\right)$} & \multicolumn{3}{|c|}{ Strain F62 (sers $)$} \\
\hline & & $1 / 1$ & $1 / 2$ & $1 / 4$ & $1 / 1$ & $1 / 2$ & $1 / 4$ \\
\hline TSB & & 0 & 0 & 7 & 100 & 98 & 98 \\
\hline $\mathrm{TSB}+2 \mathrm{mM}-\mathrm{Mg}^{2+}$ & & 0 & 0 & 6 & 100 & 98 & 89 \\
\hline TSB/GBSS & & 0 & 2 & 0 & 100 & 99 & 92 \\
\hline
\end{tabular}

* Details of media and experimental conditions are described in Methods.

effect on complement activity. However, incubation of NHS with LPS extracted from four different $\operatorname{ser}^{\mathrm{s}}$ strains clearly inhibited bactericidal activity of NHS against three of these ser ${ }^{\mathrm{s}}$ strains (Fig. 2). Complete inhibition of bactericidal activity was achieved by adding $20 \mu \mathrm{g}$ LPS to the reaction mixture serum, i.e. well below the amount shown to have no effect on complement activity. In contrast, LPS from three ser $^{r}$ strains were essentially unable to inhibit bactericidal activity against these ser ${ }^{\mathrm{s}}$ strains.

Effect of molecular size of LPS. Because the chromatographic properties of LPS might differ considerably from those of the globular proteins used to calibrate the system, it was decided to use LPS from isogenic mutants of $S$. minnesota to assess the accuracy of molecular size estimates. When the \% KDO in the LPS of the Ra, $\mathrm{RcP}^{-}$and Re mutants of $S$. minnesota were each plotted against the molecular weight estimated by column chromatography, the correlation was described by a broad parabolic function with $R^{2}=$ 0.998 (Fig. 3). From the position of the apex of the described parabola, it was apparent that the system overestimated molecular weight as LPS became increasingly hydrophobic (i.e. rough).

The validity of this technique was further verified by comparing the estimated molecular weight of each mutant LPS with that derived from their known chemical structures (Table 2). Allowing for the tendency of hydrophobicity to increase the apparent size, there was a consistent relationship between molecular weights determined by the two methods. 

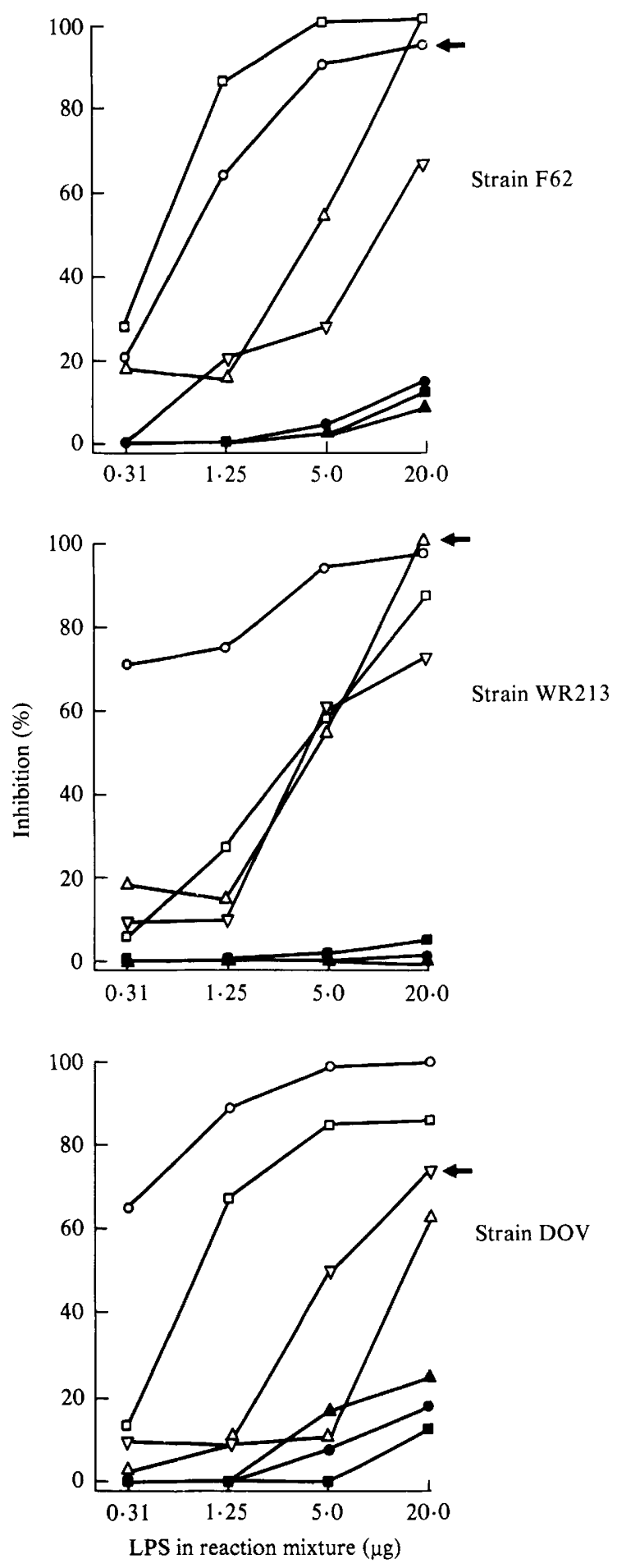

Fig. 2. LPS inhibition of NHS bactericidal activity for three $\operatorname{ser}^{s}$ strains of $N$. gonorrhoeae. NHS was used at dilutions of $1 / 20$ with strain F62,1/16 with WR213 and $1 / 12$ with DOV. LPS extracts tested were from $\operatorname{ser}^{\mathrm{s}}$ strains F62 (O), WR213 $(\triangle), \operatorname{DOV}(\nabla)$ and GC56 (口), and ser strains $7134(\mathbf{O})$, WR302 (A) and GC33 ( $\mathbf{(})$. The homologous LPS in each test is indicated by an arrow. 


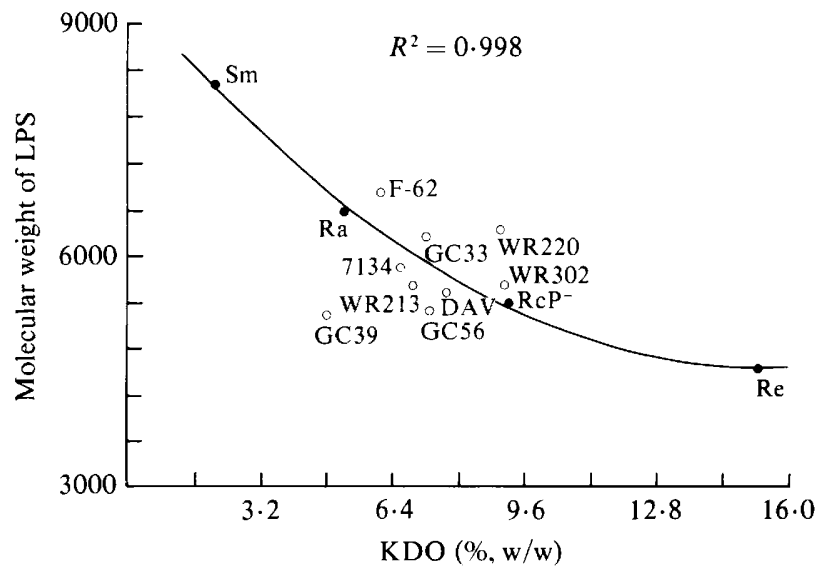

Fig. 3. Correlation of the KDO content of the LPS of a smooth strain of S. minnesota $(\mathrm{Sm})$ and three of its isogenic rough LPS mutants, and of nine strains of $N$. gonorrhoeae, with the molecular weights of their LPS as determined by chromatography using a $3 \mathrm{~m}$ column of Sephadex G-50 Superfine.

Table 2. Molecular weights of Salmonella minnesota rough LPS derived from chemical structure and by Sephadex gel filtration

\begin{tabular}{|c|c|c|c|c|}
\hline \multirow[b]{2}{*}{ Strain } & \multirow{2}{*}{$\begin{array}{l}\text { LPS } \\
\text { type }\end{array}$} & \multicolumn{2}{|c|}{ Molecular weight estimated by: } & \multirow{2}{*}{$\begin{array}{c}\text { Molecular } \\
\text { weight } \\
\text { ratio }\end{array}$} \\
\hline & & Chemical structure* & Column chromatography ${ }^{\dagger}$ & \\
\hline 112 & $\mathrm{Ra}$ & $4311 \quad(5 \cdot 0$ & $6591(5 \cdot 2) \S$ & 1.53 \\
\hline SF 1119 & $\mathrm{RcP}^{-}$ & $3155 \quad(8.0)$ & $5412 \quad(9.2)$ & 1.73 \\
\hline SF 1167 & $\mathrm{Re}$ & $2535(16.0)$ & $4549(15 \cdot 2)$ & 1.79 \\
\hline
\end{tabular}

* Derived from the chemical structure of Luderitz \& Westphal (1966); molecular weight of Lipid A $=1650$.

$\dagger$ Determined by co-chromatography with globular proteins (see Methods).

\$Values in parentheses are \% KDO values estimated by calculation from chemical structure.

$\S$ Values in parentheses are \% KDO values determined colorimetrically (see Methods).

Table 3. Chemical composition of the LPS of four ser and four ser strains of Neisseria gonorrhoeae

Hexose and KDO were determined colorimetrically. Sugars were determined by g.l.c. and are expressed as molar ratios relative to galactose $(=1.00)$ : heptose was detected in all preparations but was not quantified. Fatty acids were determined by g.l.c. and are expressed as molar ratios relative to lauric acid $(=1 \cdot 00)$.

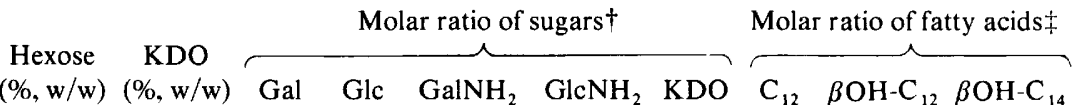

Strain $\mathrm{S} / \mathrm{R}^{*}(\%, \mathrm{w} / \mathrm{w})(\%, \mathrm{w} / \mathrm{w})$ Gal Glc $\mathrm{GalNH}_{2} \quad \mathrm{GlcNH}_{2} \mathrm{KDO} \mathrm{C}_{12} \quad \beta \mathrm{OH}-\mathrm{C}_{12} \quad \beta \mathrm{OH}-\mathrm{C}_{14}$

$\begin{array}{llllllllllll}\text { GC39 } & \text { S } & 45.9 & 4.8 & 1.00 & 0.76 & 0.19 & 0.36 & 0.34 & 1.00 & 2.99 & 4.00 \\ \text { F62 (lot 1) } & \text { S } & 25.1 & 6.1 & 1.00 & 0.68 & 0.47 & 1.18 & 1.05 & 1.00 & 0.18 & 0.17 \\ \text { F62 (lot 2) } & \text { S } & 25.3 & 6.3 & 1.00 & 0.69 & 0.40 & 1.00 & 0.88 & 1.00 & 0.26 & 0.24 \\ \text { 7134 } & \text { R } & 39.0 & 6.6 & 1.00 & 0.63 & \text { ND } & 0.54 & 0.41 & 1.00 & 0.04 & 0.06 \\ \text { WR213 } & \text { S } & 26.9 & 6.9 & 1.00 & 0.78 & \text { ND } & 1.00 & 0.80 & 1.00 & 0.09 & 0.08 \\ \text { GC33 } & \text { R } & 31.1 & 7.2 & 1.00 & 0.73 & \text { ND } & 0.80 & 0.64 & 1.00 & 1.64 & 1.31 \\ \text { GC56 } & \text { S } & 31.5 & 7.3 & 1.00 & 0.91 & \text { ND } & 0.71 & 0.56 & 1.00 & 0.52 & \text { ND } \\ \text { WR220 } & \text { R } & 32.0 & 9.0 & 1.00 & 0.78 & \text { ND } & 0.84 & 0.94 & 1.00 & 0.06 & 0.15 \\ \text { WR302 } & \text { R } & 26.5 & 9.1 & 1.00 & 0.76 & \text { ND } & 0.32 & 1.04 & 1.00 & 1.34 & 1.34\end{array}$

ND, Not detected.

* S, serum-sensitive; $R$, serum-resistant.

$\dagger$ Gal, galactose; Glc, glucose; GalNH ${ }_{2}$, galactosamine; $\mathrm{GlcNH}_{2}$, glucosamine.

$\ddagger \mathrm{C}_{12}$, lauric acid; $\beta \mathrm{OH}-\mathrm{C}_{12}, \beta$-hydroxylauric acid: $\beta \mathrm{OH}-\mathrm{C}_{14}, \beta$-hydroxymyristic acid. 
The estimated molecular weights of the LPS of gonococcal strains, when similarly plotted, clustered about those of the $\mathrm{Ra}$ and $\mathrm{RcP}^{-} S$. minnesota mutants (Fig. 3). While the LPS of $\operatorname{ser}^{r}$ strains tended to be larger than that of $\operatorname{ser}^{\mathrm{s}}$ strains, there was no clear distinction.

Effect of differences in chemical composition between LPS of sers and ser ${ }^{r}$ strains. Table 3 lists the chemical composition of the LPS extracted from four $\operatorname{ser}^{\mathrm{s}}$ and four ser strains of $N$. gonorrhoeae in order of increasing \% KDO. LPS from the eight strains differed markedly in their KDO and hexose contents as well as in the molar ratios of both their sugar and fatty acid constituents. The range of values was considerably greater than that between two lots of LPS extracted from the same strain. No consistent pattern of differences separated $\operatorname{ser}^{r}$ from ser $^{\mathrm{s}}$ strains; the LPS with the lowest $\% \mathrm{KDO}$ and highest \% hexose was from a ser ${ }^{\mathrm{s}}$ strain.

\section{DISCUSSION}

The experiments described here utilized the serum-dilution BCT rather than the inoculum-dilution BCT, since the former readily discriminates $\operatorname{ser}^{\mathrm{r}}$ from $\operatorname{ser}^{\mathrm{s}}$ strains (Rice et al., 1980). Furthermore, it yields unambiguous end-points and permits comparison with results from other workers (Schoolnik et al., 1976; Brooks et al., 1976; Petersen et al., 1976; Tramont et al., 1977; Ward et al., 1978; Rice et al., 1980). Since animal models have been uniformly misleading in the study of immune lysis of N. meningitidis (Zollinger et al., 1979), we confined our studies to serum resistance as it is manifested in human serum.

To a degree, the designations $\operatorname{ser}^{\mathrm{r}}$ and $\operatorname{ser}^{\mathrm{s}}$ are arbitrary as demonstrated in Fig. 1. In reality a continuum probably exists, in which strains may be susceptible to the lytic action of a few or many normal human sera (Glynn \& Ward, 1970). Although arbitrary, the criteria we adopted permitted comparison between strains at either end of the continuum.

Tris-containing medium (TSB) failed to sensitize $\operatorname{ser}^{\mathrm{r}}$ strains to lysis by NHS as would be the case for ser enterobacteriaceae. This indicates that physical interference with attachment of $\overline{\mathrm{C} 5 \mathrm{~b}}$ to the lipid bilayer does not account for $\operatorname{ser}^{\mathrm{r}}$ among strains of $N$. gonorrhoeae (Reynolds et al., 1975). Since the addition to NHS of exogenous lytic Ig, free of other components, resulted in lysis of the $\operatorname{ser}^{r}$ organisms, $\operatorname{ser}^{r}$ cannot reflect intrinsic resistance of the outer membrane to activated human complement; since the NHS used lysed ser ${ }^{\mathrm{s}}$ strains, it cannot be deficient in terminal complement components.

The hydrophobic nature of the lipid portion of LPS makes estimation of the molecular weights of intact LPS very difficult. Various methods developed for this purpose consistently overestimate molecular size by factors of 3 to 4 (Galanos, 1975). We chose to estimate molecular size using gel filtration of deoxycholate-disaggregated LPS since it permits analysis of the native molecule in aqueous buffer. In addition, it permits analysis of gonococcal LPS without making tenuous assumptions about its structure derived from those of enterobacterial LPS. Our results indicate molecular sizes for the LPS of $S$. minnesota mutants that are closer to their ideal sizes (based on chemical structure) than any previously reported method.

If long polysaccharide chains of the LPS of $\operatorname{ser}^{r}$ strains of $N$. gonorrhoeae protect them from immune lysis by masking lytic antigenic loci or by directing the antigen-antibody binding to distal antigenic sites which cannot function as loci for immune lysis, then physical and/or chemical differences between the LPS of $\operatorname{ser}^{r}$ and $\operatorname{ser}^{\mathrm{s}}$ strains should be readily apparent. Although the LPS of the strains we studied differed markedly in their molecular size and in the composition of their lipid and polysaccharide components, there were no consistent differences between the LPS from $\operatorname{ser}^{\mathrm{r}}$ and $\operatorname{ser}^{\mathrm{s}}$ strains. The molecular size of the LPS of one of the $\operatorname{ser}^{\mathrm{s}}$ strains was greater than that of LPS of any of the $\operatorname{ser}^{\mathrm{r}}$ strains while the \% KDO content of the LPS of two ser strains was nearly twice that of the LPS of the ser ${ }^{\mathrm{s}}$ strain of lowest KDO content. Therefore, differences in length of polysaccharide substituents alone cannot account for differences in serum sensitivity. Finally, neither the presence of $\operatorname{IgA}$ nor of blocking IgG can explain serum resistance as defined by the serum-dilution BCT. 
The arbitrary designation of strains as $\operatorname{ser}^{\mathrm{s}}$ or $\operatorname{ser}^{r}$ is supported by antigenic differences in their LPS. Nonetheless, differences in antigenic structure among the LPS of ser strains are apparent. Also, the inclusion, in the set of sera tested, of serum from a different donor might well alter the quantitative order of the inhibitory capacity of these $\operatorname{ser}^{\text {s }}$ LPS. Antigenic differences among the LPS of $\operatorname{ser}^{r}$ strains cannot be assessed in a human system, but also may exist. Finally, analysis of strains which are sensitive to some, but not all, samples of NHS may explicate the interplay between LPS antigenic loci expressed by the bacterium and prevalence of antibody specific for these loci among populations of normal humans.

We are left, then, with the simplest explanation for $\operatorname{ser}^{\mathrm{r}}$; normal human sera lack antibody specific for antigens within the LPS of $\operatorname{ser}^{r}$ strains, but contain IgM directed against antigens within the LPS of $\operatorname{ser}^{s}$ strains. LPS of both $N$. meningitidis and $N$. gonorrhoeae are antigenically diverse (Zollinger \& Mandrell, 1977; Glynn \& Ward, 1970) and it is clear that only a restricted subset of their total antigenic determinants serve as lytic loci (Glynn \& Ward, 1970; Griffiss \& Goroff, 1981). Lytic antigenic loci within the LPS of ser ${ }^{\mathrm{s}}$ and ser strains clearly differ. Precise characterization of these differences will require determination of the fine structure of LPS from sensitive and resistant strains.

It is unclear whether humans are capable of responding to the lytic antigenic loci of the LPS of ser ${ }^{r}$ strains. Both Brooks et al. (1976) and Rice et al. (1980) have reported that the bactericidal antibody response of patients with disseminated gonococcal infections is variable and meagre when the infecting strain is relatively $\operatorname{ser}^{r}$. If humans are incapable of responding immunologically to the $\operatorname{ser}^{r}$ LPS lytic antigenic loci, prevention of disseminated gonococcal disease by inducing anti-LPS antibody may not be feasible.

\section{REFERENCES}

Bertram, M. A., Griffiss, J. McL. \& Broud, D. D. (1976). Response to antigenic determinants of Neisseria meningitidis lipopolysaccharide investigated with a new radioactive antigen-binding assay. Journal of Immunology 116, 842-846.

Bhatt, T., Chambers, R. E. \& Clamp, J. R. (1970). The gas chromatographic properties of biologically important $\mathrm{N}$-acetylglucosamine derivatives, monosaccharides, disaccharides, trisaccharides, tetrasaccharides and pentasaccharides. Biochimica et biophysica acta 222, 339-347.

Brooks, G. F., Israel, K. S. \& Peterson, B. H. (1976). Bactericidal and opsonic activity against Neisseria gonorrhoeae in sera from patients with disseminated gonococcal infection. Journal of Infectious Diseases 134, 450-462.

Frank, M. M. (1979). The complement system in host defense and inflammation. Review's of Infectious Diseases 1, 483-501.

Galanos, C. (1975). Physical state and biological activity of lipopolysaccharides. Toxicity and immunogenicity of the Lipid A component. Zeitschrift für Immunitätsforschung und experimentelle Therapie 149, 214-229.

Galanos, C., Luderitz, O. \& Westrhal, O. (1969). A new method for the extraction of $\mathrm{R}$ lipopolysaccharides. European Journal of Biochemistry 9. 245-249.

GLYNN, A. A. \& WARD, M. E. (1970). Nature and heterogeneity of the antigens of Neisseria gonorrhoeae involved in the serum bactericidal reaction. Infection and Immunity 2, 162-168.

GoldSCHNEIDER, I., Gotschlich, E. C. \& Artenstein, M. S. (1969). Human immunity to the meningococcus. I. The role of humoral antibodies. Journal of Experimental Medicine 129, 1307-1326.

Griffiss, J. MCL. \& Bertram, M. A. (1977). Immunoepidemiology of meningococcal disease in military recruits. II. Blocking of serum bactericidal activity by circulating IgA early in the course of invasive disease. Journal of Infectious Diseases 136, 733-739.

Griffiss, J. MCL. \& GorofF, D. K. (1981). Immunological cross-reaction between a naturally occurring galactan, agarose, and an LPS locus for immune lysis of Neisseria meningitidis by human sera. Clinical and Experimental Immunology 43, 20-27.

Griffiss, J. MCL., Bertram, M. A. \& Broud, D. D. (1978). Separation and purification of immunoglobulins M, A and G from small volumes of human sera by a continuous, in-line chromatographic process. Journal of Chromatography 156, 121-130.

Hook, W. A. \& Muschel, L. (1964). Anticomplementary effects and complement activity of human sera. Proceedings of the Society for Experimental Biology and Medicine 117, 292-297.

KellogG, D. S., Peacock, W. L., Deacon, W. E., Brown, L. \& Pirkle, C. I. (1963). Neisseria gonorrhoeae. I. Virulence genetically linked to clonal variation. Journal of Bacteriology 85, 1274-1279.

Luderitz, O. \& Westphal, O. (1966). The significance of enterobacterial mutants for the chemical investigation of their cell-wall polysaccharides. Angewandte Chemie (International Edition) 5, 198-210.

McCutchan, J. A., Katzenstein, D., Norquist, D., Chikami, G., Wunderlich, A. \& Braude, A. I. (1978). Role of blocking antibody in disseminating 
gonococcal infection. Journal of Immunology 121, 1884-1888.

Nicholson, A. \& Lepow, I. H. (1979). Host defense against Neisseria meningitidis requires a complement-dependent bactericidal activity. Science 205, 298-299.

Osborn, M. J. (1963). Studies on the Gram-negative cell wall. I. Evidence for the role of 2-keto-3deoxyoctonate in the lipopolysaccharide of Salmonella typhimurium. Proceedings of the National Academy of Sciences of the United States of America 50, 499-506.

Petersen, B. H., Graham, J. A. \& Brooks, G. F. (1976). Human deficiency of the eighth component of complement: the requirement of $\mathrm{C} 8$ for serum Neisseria gonorrhoeae bactericidal activity. Journal of Clinical Investigation 57, 283-290.

Pier, G. B., Sidberry, H. F., Zolyomi, S. \& S Adoff, J. C. (1978). Isolation and characterization of a high-molecular-weight polysaccharide from the slime of Pseudomonas aeruginosa. Infection and Immunity 22, 908-918.

Reynolds, B. L. \& Pruul, H. (1971). Protective role of smooth lipopolysaccharide in the serum bactericidal reaction. Infection and Immunity 4, 764-771.

REYNOLDS, B. L. \& Rowley, D. (1969). Sensitization of complement-resistant bacterial strains. Nature, London 221, 1259-1261.

ReYnolds, B. L., Rother, U. A. \& Rother, K. O. (1975). Interaction of complement components with a serum-resistant strain of Salmonella typhimurium. Infection and Immunity 11, 944-948.

Rice, P. A., McCormack, W. M. \& Kasper, D. L. (1980). Natural serum bactericidal activity against Neisseria gonorrhoeae isolates from disseminated, locally invasive, and uncomplicated disease. Journal of Immunology 124, 2105-2109.

RoE, J. H. (1955). The determination of sugar in blood and spinal fluid with the anthrone reagent. Journal of Biological Chemistry 212, 335-343.
Schneider, H., Griffiss, J. McL., Williams, G. D. \& PIER, G. B. (1978). Noncorrelation of Neisseria gonorrhoeae serum sensitivity and serum resistance with molecular weight of gonococcal lipopolysaccharides. In Immunobiology of Neisseria gonorrhoeae, pp. 196-198. Edited by G. F. Brooks, E. C. Gotschlich, K. K. Holmes, W. D. Sawyer \& F. E. Young. Washington: American Society for Microbiology.

Schoolnik, G. K., Buchanan, T. M. \& Holmes, K. K. (1976). Gonococci causing disseminated gonococcal infections are resistant to the bactericidal action of normal human sera. Journal of Clinical Investigation 58, 1163-1173.

Tramont, E. C., Sadoff, J. C. \& Wilson, C. (1977). Variability of the lytic susceptibility of Neisseria gonorrhoeae to human sera. Journal of Immunology 1 18, 1843-1851.

Ward, M. E., Lambden, P. R., Heckels, J. E. \& WATt, P. J. (1978). The surface properties of Neisseria gonorrhoeae: determinants of susceptibility to antibody complement killing. Journal of General Microbiology 108, 205-212.

WestPhal, O. \& JANN, K. (1965). Bacterial lipopolysaccharides. Methods in Carbohydrate Chemistry 5, 83-91.

White, L. \& KellogG, D. S. (1965). Neisseria gonorrhoeae identification in direct smears by a fluorescent antibody-counterstain method. Applied Microbiology 13, 171-174.

Zollinger, W. D., \& MANDrell, R. E. (1977). Outer membrane protein and lipopolysaccharide serotyping of Neisseria meningitidis by inhibition of a solid phase radioimmunoassay. Infection and Immunity 18, 424-433.

Zollinger, W. D., Mandrell, R. E., Griffiss, J. McL., Altieri, P. L. \& Bertram, S. (1979). Complex of meningococcal group B polysaccharide and type 2 outer membrane protein immunogenic in man. Journal of Clinical Investigation 63, 836-848. 